\title{
Unusual Monteggia type 1 variant in adult: a rare finding in a rare fracture
}

\author{
Mantu Jain, ${ }^{1}$ Amit Tirpude ${ }^{2}$
}

'Department of Orthopedics, All India Institute of Medical Sciences, Bhubaneswar, Odisha, India

${ }^{2}$ Anatomy, All India Institute of Medical Sciences, Bhubaneswar, Odisha, India

\section{Correspondence to}

Dr Mantu Jain,

montu_jn@yahoo.com

Accepted 19 July 2018

\section{DESCRIPTION}

A 56-year-old female patient presented to the orthopaedic outpatient department with alleged history of slip from stairs about 10-12 in number and fall on the outstretched hand about 3 weeks ago. Following the injury, she developed severe pain, swelling abnormal mobility of lower arm and restriction of movement of the right elbow. She also admitted that post trauma, she had received treatment from traditional bone setters which had reduced her pain. On examination of her limb, there was a flexion deformity of right elbow along with extra articlar varus deformity of lower arm which was mobile with tenderness and bony crepitus at both at arm and the elbow. There was no distal neurovascular deficit.

Radiographs of the right arm and forearm with shoulder, elbow and wrist joints revealed fractures of the lower shaft humerus and proximal ulna (metaphyseal with intra-articular fragment and coronal split from metaphyio-diaphysis junction extending up to half of shaft of ulna). There was associated radial head dislocation anteriorly (figure 1).

Under general anaesthesia, using the dorsal approach, open reduction and internal fixation of the humerus followed by the ulna was done using contoured locking contoured plate (LCP) and cerclage wiring. The radial head was irreducible and hence excised through the Boyd's approach. Postoperatively, the forearm was immobilised in an aboveelbow slab (figure 2). There was no radial nerve or postinterosseous nerve palsy postoperatively. At 3 weeks, physiotherapy with range of movement was started, and the patient gained $90^{\circ}$ elbow flexion and a near full pronation-supination movement at 6 months follow-up.

Monteggia fracture-dislocation is a rare injury in both adults and children. ${ }^{12}$ The diagnosis is often missed in the trauma and emergency department, necessitating a thorough clinical examination and

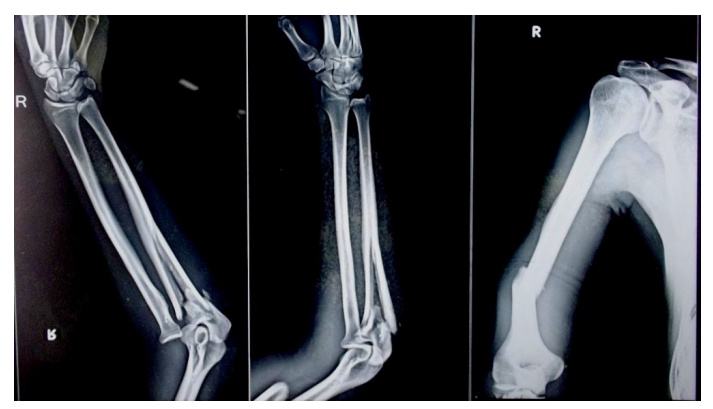

Figure 1 A plain X-ray of the arm with elbow and forearm showing fracture of distal shaft humerus and the 'atypical' Monteggia variant.

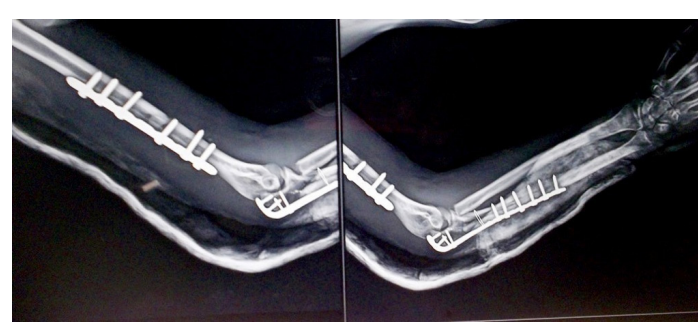

Figure 2 A postoperative plain X-ray of the same patient with internal fixation of the humerus and ulna along with radial head excision.

radiographic interpretation. ${ }^{1}$ The injury has been described variously but Bado's classification remains the most acceptable. Along with its classical four types, there are several variants described, particularly with type 1 and more so in the children group as type 1 is more common in the children. ${ }^{3}$ Ours is a unique finding seen in adults that fits best as a variation of type 1 . To add to our woe, the patient had a massage therapy by a traditional bone setter and hence presented late. The purpose is to highlight the imaging of the 'rare of a rare' fracture pattern rather than discussing the management part.

\section{Learning points}

- Our case is unique which has never been described previously in literature and hence it is a 'rare in the rare' finding.

- Type 1 and its variant is more common in children but this was seen in an adult.

- To add to the existing problems, she underwent a therapy by a traditional bone setter which we consider would require surgical treatment

Contributors MJ admitted the patient and operated him. MJ and AT reviewed the literature and wrote the paper.

Funding The authors have not declared a specific grant for this research from any funding agency in the public, commercial or not-for-profit sectors.

Competing interests None declared.

\section{Patient consent Obtained.}

Provenance and peer review Not commissioned; externally peer reviewed.

\section{REFERENCES}

1 Williams HLM, Madhusudhan TR, Sinha A. Type III monteggia injury with ipsilateral type II Salter Harris injury of the distal radius and ulna in a child: a case report. BMC Res Notes 2014;7:156-6.

2 Sajjan SS, Hegde AS, Annappa R, et al. Monteggia Type 1 Fracture Equivalent with Concomitant Ipsilateral Distal Radius and Ulna Fracture in an Adult: A Rare Case Report. J Clin And Diagnostic Res 2017

include Day Month Year] doi:10.1136/bcr-2018226789 
Copyright 2018 BMJ Publishing Group. All rights reserved. For permission to reuse any of this content visit http://group.bmj.com/group/rights-licensing/permissions.

BMJ Case Report Fellows may re-use this article for personal use and teaching without any further permission.

Become a Fellow of BMJ Case Reports today and you can:

- Submit as many cases as you like

- Enjoy fast sympathetic peer review and rapid publication of accepted articles

Access all the published articles

- Re-use any of the published material for personal use and teaching without further permission

For information on Institutional Fellowships contact consortiasales@bmjgroup.com

Visit casereports.bmj.com for more articles like this and to become a Fellow 